\title{
Albumin and total protein concentration - selected parameters of catabolic reaction and nutritional status among patients with craniocerebral injuries diagnosed with surgically treated cerebrovascular diseases
}

\section{Stężenie albumin i białka całkowitego - wybrane parametry reakcji katabolicznej i stan odżywienia pacjentów z urazami czaszkowo-mózgowymi i rozpoznanymi chorobami naczyń mózgowych leczonych chirurgicznie}

\author{
Lucyna Ścisło, Magdalena Staszkiewicz, Elżbieta Walewska, Stanisław Wojtan, Małgorzata Paplaczyk, \\ Maria Kózka
}

Department of Clinical Nursing, Institute of Nursing and Midwifery, Faculty of Health Sciences, Jagiellonian University Medical College, Krakow, Poland

Head of the Department: Prof. Maria Kózka PhD

Key words: nutritional status, albumin, total protein, NRS 2002, catabolism.

Słowa kluczowe: stan odżywienia, albumina, białko całkowite, NRS 2002, katabolizm.

\begin{abstract}
Introduction: Posttraumatic metabolic disorders, including surgeries, generate a large energy expenditure in humans. They may lead to hypermetabolism, hypercatabolism, and hyperglycaemia, resulting in a severe condition of patients, which may require intensive care unit (ICU) treatment. The basic feature of the catabolism phase is the breakdown of muscle protein, due to which patients require urgent nutritional intervention. The necessity for nutritional support is assessed, among others, by measuring the level of protein and albumin.

Aim of the research: To evaluate the level of total protein and albumin as indicators of metabolic disorders in patients after surgical procedures due to craniocerebral injuries and cerebrovascular diseases, in order to confirm the need for nutritional treatment.

Material and methods: The study included 152 patients treated in the ICU, aged between 19 and 89 years. Seventy-one subjects were diagnosed with cerebrovascular disease (Group I) and 81 with cranial and cerebral trauma (Group II) and were after neurosurgery. Retrospective analysis of documentation and laboratory results was employed to assess the level of total protein and albumin on the day of admission to the ICU.

Results: Low levels of albumin were found in both groups (Group I: 75\%, Group II: 76\%) and of total protein (Group I: 69\%, Group II: 71\%), which indicated different degrees of malnutrition in the patients. On the day of admission, Group I showed higher albumin levels $(p=0.039)$ compared with Group II.

Conclusions: Low levels of albumin in both study groups indicate an intensified catabolic reaction of the body associated with extensive trauma and the need for nutritional treatment.
\end{abstract}

\section{Streszczenie}

Wprowadzenie: Zaburzenia metaboliczne w odpowiedzi na uraz, w tym zabieg chirurgiczny, generują duży wydatek energetyczny organizmu. Prowadzą do hipermetabolizmu, hiperkatabolizmu i hiperglikemii, czego skutkiem jest ciężki stan chorych wymagających leczenia na oddziale intensywnej opieki medycznej (OIOM). Zasadniczą cechą fazy katabolizmu jest rozpad białka, zawartego w mięśniach, co powoduje, że pilna jest interwencja żywieniowa pacjentów m.in. na podstawie poziomu kontrolowanego białka i albumin.

Cel pracy: Ocena poziomu albumin i białka całkowitego jako wybranych parametrów reakcji katabolicznej i stanu odżywienia u pacjentów po zabiegach chirurgicznych z powodu urazów czaszkowo-mózgowych oraz chorób naczyniowych mózgu, dla potwierdzenia prowadzenia leczenia żywieniowego.

Materiał i metody: Badaniem objęto 152 pacjentów leczonych na OIOM, u których wykonano zabieg neurochirurgiczny, w wieku 19-89 lat, w tym 71 osób z rozpoznaniem choroby naczyniowej mózgu (grupa I) oraz 81 z urazem czaszkowo-mózgowym (grupa II). W pracy wykorzystano metodę retrospektywnej analizy dokumentacji i wyników badań laboratoryjnych. Analizowano stężenia albumin i białka całkowitego w dniu przyjęcia na OIOM. 
Wyniki: W obydwu grupach badanych, w dniu przyjęcia na IOM, stwierdzono obniżony poziom albumin wskazujący na niedożywienie (grupa I - 75\%, II - 75\%) oraz białka całkowitego (grupa I - 69\%, II - 71\%), u badanych z grupy I wykazano wyższe stężenie albumin $(\mathrm{p}=0,039)$ w porównaniu z grupą II.

Wnioski: Niski poziom albuminy w obu badanych grupach wskazuje na wzmożoną reakcję kataboliczną organizmu związaną z rozległym urazem i koniecznością leczenia żywieniowego.

\section{Introduction}

A surgical procedure is an intervention in the body; the larger the injury, the stronger the catabolic response. As a result of catabolism, retention of sodium ions and water in the body is initiated, there is pain reduction, and an increase in blood glucose levels caused by glycolysis, gluconeogenesis, and glycogenolysis. Next, there is a fat breakdown, increased concentration of ketone bodies, as well as protein breakdown, loss of nitrogen in urine and negative nitrogen balance, and modulation of the immune system, which is a response to inflammatory stimuli [1-3].

The main source of proteins released by peripheral tissues is from skeletal muscles. During an injury, their massive proteolysis occurs. Amino acids are used as substrates for gluconeogenesis in the liver. The amount of glucose obtained from burning $100 \mathrm{~g}$ of protein is $57 \mathrm{~g}$, and to provide enough energy to protect the brain requires $200 \mathrm{~g}$ of protein. Amino acids released from muscles are also used for the production of acute phase proteins, complement factors, albumin, and glycoproteins. The urinary excretion of nitrogenous residues increases to $30 \mathrm{~g}$ per day. This, in turn, implies a decrease in the patient's body weight by an average of $1.5 \%$ per day. Without the implementation of nutritional intervention, within 10 days, $15 \%$ of body weight is lost [4]. Proteolysis of the muscle tissue leads to atrophy and weakening of muscle strength, dysfunction of internal organs, and lowered immunity [5].

Total protein is one of the elements used to assess the system's protein balance. Its concentration in serum provides general information on the nutritional status of the patient. About $50-60 \%$ of total protein is albumin, the remaining percentage is globulin, fibrinogen, lipoprotein, and glycoprotein. The main causes of reduced total protein levels in the blood $(<60 \mathrm{~g} / \mathrm{l})$ are disorders of protein synthesis (e.g. malnutrition, cancer, absorption disorders), increased protein loss (e.g. in trauma, nephrotic syndrome, cancer, burns), and increased catabolism (e.g. in an injury, cachexia). Low values of total protein in blood are often accompanied by low levels of albumin. Biochemical tests involving the levels of albumin and protein are useful in the diagnosis of protein-caloric malnutrition [6].

An indicator for the assessment of the initial nutritional status is albumins for which the serum concentration correlates with an increased frequency of complications. However, the half-life of albumin of 18-21 days does not allow monitoring of rapid changes in the nutritional status of patients during nutritional treatment. In patients with a worsening clinical condition, hypoalbuminaemia is not considered as a consequence of malnutrition, but rather as its progression. It is also an indicator of the ongoing inflammatory process, the severity of the disease, and the body's hydration status (excess of hypotonic or electrolyte-free fluid). Low levels of albumin also occur in patients using drugs that bind to albumin, such as glucocorticosteroids [6].

The body reacts with a catabolic response also in patients with cerebral vascular diseases and craniocerebral trauma treated in intensive care units (ICUs). Additionally, surgical medical interventions among this group of patients lead to intensification of the catabolism phase. The main feature of the catabolism phase is the disintegration of the protein contained in the muscles, due to which urgent nutritional intervention of patients is required based on, among others, controlling the level of protein [7].

\section{Aim of the research}

The aim of the study was to assess the level of albumin and total protein as selected parameters of catabolic reaction and nutritional status in patients after surgery due to cerebral vascular diseases and craniocerebral trauma.

\section{Material and methods}

The study analysed the documentation of 152 patients, aged $19-89$ years $(\mathrm{M}=55.34)$, who underwent neurosurgical procedures. The diagnosis of cerebral vascular disease (subarachnoid haemorrhage, intracerebral haemorrhage) amounted to $71(46.7 \%)$ patients, and $81(53.3 \%)$ patients were diagnosed with craniocerebral trauma (subdural, focal, and diffuse brain injury).

The study included patients who underwent urgent surgery, treated in the intensive care unit in the period from January 2015 to January 2017. The paper uses the method of retrospective analysis of medical records and laboratory results.

On the basis of the documentation on admission to the ICU after surgery, the study included a screening nutritional assessment of NRS 2002 (2002 Nutrition Risk Score) and establishes the patients' body mass index (BMI).

According to NRS 2002, the total score $\geq 3$ means the risk of malnutrition and the need to start nutritional therapy. 
BMI values below $18.5 \mathrm{~kg} / \mathrm{m}^{2}$ indicate underweight, and values of $18.5-24.9 \mathrm{~kg} / \mathrm{m}^{2}$ indicate normal weight. Serum albumin levels were assumed to be normal at $>35 \mathrm{~g} / \mathrm{l}$. Albumin levels of 35 and below indicate abnormal nutrition (31-35 g/l indicates slight malnutrition, 25-30.99 g/l moderate malnutrition, and $<25 \mathrm{~g} / 1$ severe malnutrition) [8]. The normal total protein level was assumed to be $60-80 \mathrm{~g} / 1[7,8]$.

Patients implemented parenteral nutrition treatment based on the nutritional screening using the Nutrition Risk Score 2002 (NRS 2002).

\section{Statistical analysis}

The results were analysed in IBM SPSS Statistics version 24 . The basic descriptive statistics of the analysed quantitative variables were calculated. Normality of their distributions was tested, and Student's $t$-tests for dependent and independent samples and Pearson's $r$ coefficient were performed. The statistical significance threshold was adopted at $\alpha=0.05$.

\section{Results}

\section{NRS 2002 scale results}

All 152 researched patients obtained results indicating the risk of malnutrition (NRS $\geq 3$ ) and the need to apply nutritional treatment.

\section{Body mass index results (BMI)}

In the group of patients with cerebrovascular disease, $30(42.3 \%)$ subjects had normal BMI. There were no subjects with results below the norm. Overweight and obesity of I and II degree was noted in 41 (57.8\%) patients. Among the patients with craniocerebral trauma, normal BMI values were found in 44 (54.3\%) patients, and $36(44.4 \%)$ patients were classified as overweight and obese in the $1^{\text {st }}$ degree. Below standard results were observed in $1(1.2 \%)$ person - Table 1.

\section{Results of albumin and total protein levels of patients with cerebrovascular disease on the day of admission to the ICU}

On the day of admission of patients with cerebrovascular diseases to the ICU, normal serum albumin levels were observed in 18 (25.3\%) patients. In the remaining $44(62 \%)$ patients, below standard albumin levels were observed, which indicated mild to moderate malnutrition; in 9 (12.7\%) patients, the interpretation of albumin values indicated severe malnutrition (Table 2).

Patients were also analysed for serum total protein levels. For those with cerebrovascular disease on the day of admission to the ICU, results in the normal range were obtained in $22(31 \%)$ patients, and results below the normal range were observed in 49 (69\%) patients (Table 3).

Results of albumin and total protein levels of patients with craniocerebral trauma on the day of admission to the ICU

On the day of admission of patients with craniocerebral injuries to the ICU, normal serum albumin

Table 1. Body mass index (BMI) values on the day of admission to the intensive care unit (ICU) of patients with cerebrovascular disease and craniocerebral trauma

\begin{tabular}{|lcccc|}
\hline BMI & \multicolumn{2}{c|}{ Patients with cerebrovascular disease } & Patients with craniocerebral trauma \\
\cline { 2 - 5 } & $\boldsymbol{N}$ & $\%$ & $\boldsymbol{N}$ & $\%$ \\
Underweight & 0 & 0 & 1 & 1.2 \\
Normal body mass & 30 & 42.3 & 44 & 54.3 \\
Overweight & 32 & 45.1 & 32 & 39.5 \\
Obesity I degree & 8 & 11.3 & 4 & 4.9 \\
Obesity II degree & 1 & 1.4 & 0 & 0 \\
\hline
\end{tabular}

$B M I$ - body mass index, $N$ - population.

Table 2. Albumin levels of patients with cerebrovascular disease on the day of admission to the ICU

\begin{tabular}{|lccccc|}
\hline Albumin $[\mathrm{g} / \mathrm{l}]$ & $\boldsymbol{N}$ & \% & Nutritional status & M & SD \\
$>35$ & 18 & 25.3 & Good & & \\
$31-35$ & 23 & 32.4 & Light malnutrition & 31.38 & 6.04 \\
$25-30.99$ & 21 & 29.6 & Moderate malnutrition & & \\
$<25$ & 9 & 12.7 & Severe malnutrition & \\
\hline
\end{tabular}

$g / l$-gram per litre, $N$ - population, $M-$ mean, $S D$ - standard deviation. 
Table 3. Protein levels of patients with cerebrovascular disease on the day of admission to the ICU

\begin{tabular}{|lccccc|}
\hline Total protein $[\mathrm{g} / \mathrm{l}]$ & $\boldsymbol{N}$ & $\%$ & Interpretation & M & SD \\
$60-80$ & 22 & 31.0 & Norm & 55.63 & 8.41 \\
$<60$ & 49 & 69.0 & Below normal & & \\
\hline
\end{tabular}

g/l-grams per litre, $N$ - population, $M-$ mean, $S D$ - standard deviation.

Table 4. Albumin levels in patients with craniocerebral trauma on the day of admission to the ICU

\begin{tabular}{|lccccc|}
\hline Albumin $[\mathrm{g} / \mathrm{l}]$ & $\boldsymbol{N}$ & $\%$ & Nutritional status & M & SD \\
$>35$ & 20 & 24.7 & Good & \\
$31-35$ & 10 & 12.3 & Light malnutrition & \\
$25-30.99$ & 30 & 37.0 & Moderate malnutrition & 29.23 & 6.63 \\
$<25$ & 21 & 25.9 & Severe malnutrition & \\
\hline
\end{tabular}

g/l-grams per litre, $N$ - population, $M-$ mean, $S D$ - standard deviation.

Table 5. Total protein levels of patients with craniocerebral trauma on the day of admission to the ICU

\begin{tabular}{|lccccc|}
\hline Total protein $[\mathrm{g} / \mathrm{l}]$ & $\boldsymbol{N}$ & $\%$ & Interpretation & $\mathbf{M}$ & SD \\
$60-80$ & 23 & 28.8 & Norm & & \\
$<60$ & 57 & 71.3 & Below normal & 54.78 & 8.29 \\
\hline
\end{tabular}

g/l-gram per litre, $N$ - population, $M$ - mean, $S D$ - standard deviation.

Table 6. Comparison of albumin and total protein levels of all subjects on the day of admission to the ICU

\begin{tabular}{|lccccccccc|}
\hline Parameter & \multicolumn{3}{c}{$\begin{array}{c}\text { Patients with } \\
\text { cerebrovascular disease }\end{array}$} & \multicolumn{2}{c}{$\begin{array}{c}\text { Patient with } \\
\text { craniocerebral trauma }\end{array}$} & \multicolumn{3}{c|}{$95 \% \mathrm{Cl}$} \\
\cline { 2 - 10 } & $\mathbf{M}$ & SD & M & SD & $T$ & $P$-value & Cl max. & Cl min. \\
Albumin & 31.38 & 6.04 & 29.23 & 6.63 & 2.078 & 0.039 & 0.106 & 4.193 \\
Total protein & 55.63 & 8.41 & 54.78 & 8.29 & 0.620 & 0.536 & -1.846 & 3.535 \\
\hline
\end{tabular}

$M$ - mean, SD - standard deviation, $T$ - Student's t-test, $p$ - statistical value, $95 \% \mathrm{Cl}$ - confidence interval, $\mathrm{Cl}$ max - confidence interval maximum, $\mathrm{Cl}$ min - confidence interval minimum.

levels were observed in $20(24.7 \%)$ patients. In the remaining 40 (49.3\%), albumin levels below normal were observed, which indicated mild to moderate malnutrition. In 21 (25.9\%) patients, the interpretation of albumin values indicated severe malnutrition. The albumin levels of patients with craniocerebral injuries are shown in Table 4 .

For patients with craniocerebral trauma, normal protein levels on the day of admission to the ICU were observed in $23(28.8 \%)$ patients, and levels below normal were seen in $57(71.3 \%)$ patients (Table 5).

Results of albumin and total protein levels of all subjects on the day of admission to the ICU

The researched groups of patients were compared in terms of albumin and total protein levels on the day of admission to the ICU. The results showed that the groups differed statistically significantly in terms of albumin levels; $p=0.039$. Patients with known craniocerebral trauma had lower albumin levels on the day of admission than patients with cerebrovascular disease (Table 6).

\section{Discussion}

Increased catabolic processes lead to a negative nitrogen balance. Within $24 \mathrm{~h}$ of injury, there is an increase in the use of glucose by the brain, blood cells, and bone marrow, leading to depletion of hepatic glycogen stores $[9,10]$. During this period, glucose supplied to the cellular system is produced in the process of gluconeogenesis. Amino acids from proteolysis of muscle tissue become a substrate in this process. Muscle breakdown generates protein loss of up to $1000 \mathrm{~g}$ in a 24 -hour period [10]. Without the implementation 
of nutritional intervention, 15\% of body weight is lost over a 10-day period [4]. Medical interventions such as surgery or pharmacotherapy also contribute to the increase in energy intake. All these processes may lead to a decrease in protein and albumin levels, resulting in the development of protein-calorie malnutrition with its consequences: increased risk of infections, lowered immunity, delayed healing of traumatic wounds, decreased response to pharmacotherapy.

In patients after craniocerebral trauma, with a history of surgery, and surgical injury due to cerebrovascular disease, malnutrition may develop due to excessive protein breakdown and increased catabolism, which results in a negative nitrogen balance and an increased need for protein and calories [11]. Caloric expenditure among these patients typically increases by $87-200 \%$ above normal requirements and may be increased for 30 days due to metabolic changes. Alteration of systematic catabolism in these patients leads to hyperglycaemia, protein loss, and increased calorie requirements $[12,13]$. The prevalence of malnutrition among the hospitalised patients in the ICU is estimated to range from $20 \%$ to $50 \%$ on the first day of stay [14-17], so it is important to monitor patients' clinical and metabolic status by, among other things, determining total protein and albumin levels.

Our study analysed the records of 152 patients, admitted as emergencies to the intensive care unit, who underwent surgery. These were patients with cerebrovascular disease and after craniocerebral trauma. Patients were analysed for albumin and total protein levels on the day of admission to the ICU.

In the group of patients with cerebrovascular disease, albumin levels below normal, indicating malnutrition, occurred in almost $75 \%$, of whom $13 \%$ had an interpretation of albumin values indicating severe malnutrition. The literature indicates that malnutrition significantly affects the general condition and hospitalisation of the patient after surgery in cases of cerebrovascular disease [18].

Similarly, in the group of patients with craniocerebral trauma, serum albumin levels below normal were found in $75 \%$ of the patients having an albumin interpretation indicating severe malnutrition. Decreased albumin levels may be indicative of the extent of the injury and the increased catabolic processes resulting from it.

One literature analysis indicates that malnutrition occurring during craniocerebral trauma negatively affected metabolic response and vice versa, thus making them vulnerable to side effects and further deterioration in nutritional status. In patients with severe trauma, the prevalence of malnutrition ranged from $7 \%$ to $76 \%$, depending on the setting, population, and nutritional assessment tool used. In contrast, in the population of elderly trauma patients $7-62.5 \%$ were malnourished on admission and $35.6-60 \%$ were at risk of malnutrition [19].
In our study, all 152 examined patients had scores indicating a risk of malnutrition (NRS $\geq 3$ ) and the need for nutritional treatment. Studies by other authors indicate that $22.3 \%$ (235) of trauma brain injury (TBI) patients were at risk of malnutrition (NRS $\geq 3$ ), while normal nutritional status (NRS $<3$ ) was diagnosed in $77.7 \%[8,20]$. The highest prevalence of malnutrition was found in general surgical patients with infected wounds $31.0 \%$ and in traumatology $35.0 \%$ [20]. In our study, based on BMI, there were no results below normal levels in the entire study group, except for 1 person with craniocerebral trauma. Based on studies by other authors, BMI is a value that does not change from the time of injury to admission [21].

The levels of protein markers (albumin, prealbumin, transferrin) reflect the acute phase of the disease. The value of these indicators has prognostic significance. Decreased albumin levels are disadvantageous in the perioperative period. Data indicate that patients with low albumin levels $(<20 \mathrm{~g} / \mathrm{l})$ on the day of surgery have a twofold increased risk of postoperative complications including increased respiratory distress and in-hospital mortality. Thus, albumin is considered a good prognostic indicator in surgically treated patients [6, 22]. Assessment of albumin levels is also helpful in determining hydration status and disease severity. Excessive fluid therapy leading to conductivity with hypotonic or electrolyte-free fluids correlates with a decrease in albumin levels $[6,8]$.

Low levels of total protein in the blood usually coexist with low levels of albumin. Hypoproteinaemia can occur in the case of ongoing inflammation by consuming pro-inflammatory factors for production. A decrease in protein concentration can result in a decrease in the body's transport and immune proteins, resulting in increased susceptibility to infection, impaired wound healing, and an increased risk of anastomotic dissection [6].

In the analysis of total protein levels in the studies conducted, similar results were observed when compared to albumin values. In the cerebrovascular disease group, the number of patients with a protein level below normal on the day of admission was $69.0 \%$, while in the craniocerebral trauma group, the number of patients with a protein level below normal on the day of admission was $71.3 \%$. The results demonstrate the need to monitor the patient's clinical status during the undertaken nutritional treatment.

In the entire study group, reduced albumin levels were found in $75 \%$ of subjects and total protein values were below normal in $70 \%$.

Patients with traumatic brain injury experience significant energy and protein deficits in the intensive care unit, which is associated with adverse outcomes. Patients admitted to the ICU with TBI have energy and protein deficiencies that persist after discharge from the ICU, leading to significant deficien- 
cies throughout the hospitalisation [23, 24]. A study among patients with mild to moderate TBI (according to the Glasgow scale) showed that a significant number of patients had reduced protein levels at the start of hospitalisation, which gradually improved after nutritional treatment (on the first day of nutritional treatment, protein levels increased by $23.1 \%$, while $75 \%$ of the total protein requirement was reached on the day of discharge). The authors of the study believe that optimal nutrient intake, especially calories and protein, is crucial to ensure an optimal recovery process, as well as minimising the risk of infection and complications [25]. A study by Stewart et al. among critically ill patients revealed that calorie and protein deficits in patients with moderate to severe TBI (Glasgow score 9-12 and 3-8, respectively), reached $18,242 \mathrm{kcal}(1 \mathrm{kcal}=4186 \mathrm{~kJ})$ and $1315 \mathrm{~g}$ protein, respectively [26]. Other researchers present results showing that $15-70 \%$ of patients already had malnutrition before hospitalisation [27].

The results presented here confirm that hypoalbuminaemia is common among severely ill patients, which also include patients with cerebrovascular diseases such as subarachnoid haemorrhage and intracerebral haemorrhage, and with craniocerebral trauma such as traumatic subdural haemorrhage, and focal and diffuse brain injury. An albumin level below normal indicates the severity of the disease, hydration status, is a prognostic indicator of surgical risk, and reflects the inflammatory response [28-31].

Malnutrition is a common problem among hospitalized patients, especially among patients with TBI. It develops as a result of hypermetabolism, and the condition can worsen with undernourishment or poor dietary management $[24,25]$. In particular, elderly trauma patients and patients with postoperative infections should be carefully monitored during hospitalisation [20].

The monitoring of protein and energy supplies is of great importance in severely ill patients, who are usually in the catabolic phase, the severity of which depends on the extent of the injury or the severity of the disease and the nutritional status of the patient. An essential feature of catabolism is the breakdown of the protein stored in the muscles, so it is important to increase the supply of protein, especially during the first days of injury, through nutritional treatment, as an important part of a comprehensive therapy that becomes a necessity and has a significant impact on the subsequent course and outcome of treatment.

\section{Conclusions}

Decreased albumin and total protein values and NRS 2002 scores of patients with cerebrovascular disease and craniocerebral trauma are indicative of impaired nutritional status. Decreased levels of albumin and protein in both study groups signify an increased catabolic reaction of the body associated with extensive trauma and indicate the need for nutritional treatment. Subjects with craniocerebral trauma showed significantly lower albumin levels compared to patients with cerebrovascular disease, which may indicate a more intense catabolic response.

\section{Conflict of interest}

The authors declare no conflict of interest.

\section{References}

1. Hasiak J. Stres okołooperacyjny - operacja. Przegl Urol 2012; 3: 9-14.

2. Sobotka L. Podstawy żywienia klinicznego. Krakowskie Wydawnictwo Scientifica, Krakow 2013; 123-127.

3. Namyslak M, Kanikowska A, Grzymislawski M. Analiza czynników ryzyka niedożywienia szpitalnego. Żyw Człow Metab 2014; 41: 5-15.

4. Simsek T, Simsek HU, Cantruk NZ. Response to trauma and metabolic changes: posttraumatic metabolism. Ulus Cerrahi Derg 2014; 30: 153-159.

5. Grylewski A, Majcher P, Szczepanik M. Immunologiczne aspekty urazu. Postępy Hig Med Dosw 2006; 60: 192-200.

6. Ławiński M, Jachnis A, Chaber A, Słodkowski M. Choroby internistyczne w okresie okołooperacyjnym. Med Po Dypl 2018; 1: 37-43.

7. Szczygieł B. Leczenie żywieniowe - postępy 2014. Med Prakt 2014; 2: 35-41.

8. Kłęk S, Pertkiewicz M. Niedożywienie. In: Szczeklik A, Gajewski P. Interna Szczeklika. Medycyna Praktyczna, Kraków 2014, 2545-2546.

9. Foley N, Marshall S, Pikul J, Salter K, Teasell R. Hypermetabolism following moderate to severe traumatic acute brain injury: a systemic review. J Neurotrauma 2008; 25: 1415-1431.

10. Pepe JL, Barba CA. The metabolic response to acute traumatic brain injury and implications for nutritional support. J Head Trauma Rehabil 1999; 14: 462-474.

11. Dickerson RN, Pitts SL, Maish GO. A reappraisal of nitrogen requirements for patients with critical illness and trauma. J Trauma Acute Care Surg 2012; 73: 549-557.

12. Costello LAS, Lithander FE, Gruen RL, Williams LT. Nutrition therapy in the optimisation of health outcomes in adult patients with moderate to severe traumatic brain injury: findings from a scoping review. Injury 2014; 45 : 1834-1841.

13. Masha'al D. The Change in Nutritional Status in Traumatic Brain Injury Patients: A Retrospective Descriptive a Retrospective Descriptive Study. Graduate Theses and Dissertations 2016.

14. Kang MC, Kim JH, Ryu SW. Prevalence of malnutrition in hospitalized patients: a multicenter cross-sectional study. J Kor Med Sci 2018; 33: e10.

15. Barker LA, Gout BS, Crowe TC. Hospital malnutrition: prevalence, identification and impact on patients and the healthcare system. Int J Environ Res Publ Health 2011; 8: 514-527.

16. Gout BS, Barker LA, Crowe TC. Malnutrition identification, diagnosis and dietetic referrals: are we doing a good enough job? Nutr Diet 2009; 66: 206-211. 
17. Pierzak M, Szczukiewicz-Markowska, Głuszek S. Problem niedożywienia szpitalnego i jego konsekwencje. Med Stud 2020; 36: 46-50.

18. Nakajima I, Kato TS, Komamura K, Takahashi A, Oda N, Sasaoka T, Asakura M, Hashimura K, Kitakaze M. Pre- and post-operative risk factors associated with cerebrovascular accidents in patients supported by left ventricular assist device. Single center's experience in Japan. Circ J 2011; 75: 1138-1146.

19. Dijkink S, Meier K, Krijnen P, Yeh DD, Velmahos GC, Schipper IB. Malnutrition and its effects in severely injured trauma patients. Eur J Trauma Emerg Surg 2020; 46: 993-1004.

20. Ihle C, Freude T, Bahrs C, Zehendner E, Braunsberger J, Biesalski HK, Lambert C, Stöckle U, Wintermeyer E, Grünwald J, Grünwald L, Ochs G, Flesch I, Nüssler A. Malnutrition - an underestimated factor in the inpatient treatment of traumatology and orthopedic patients: a prospective evaluation of 1055 patients. Injury 2017; 48: 628-636.

21. Gubari MIM, Hosseinzadeh-Attar MJ, Hosseini M, Mohialdeen FA, Norouzy A. Association of high serum adiponectin with the risk of malnutrition and worse outcome in head trauma patients: a cohort study. Arch Acad Emerg Med 2019; 7: e43.

22. Szczygieł B, Ukleja A. Jak rozpoznać i leczyć niedożywienie związane z chorobą? Wydawnictwo Lekarskie PZWL Warszawa 2017.

23. Chapple LS, Chapman MJ, Lange K, Deane AM, Heyland DK. Nutrition support practices in critically il head-injured patients: a global perspective. Crit Care 2016; 20: 6.

24. Krakau K, Hansson A, Karlsson T. Nutritional treatment of patients with severe traumatic brain injury during the first six months after injury. Nutrition 2007; 23: 308-317.

25. Abdullah MI, Ahmad A, Wafa S, Latif AZA, Yusoff NAM, Jasmiad MK, Udin N, Karim KA. Determination of calorie and protein intake among acute and sub-acute traumatic brain injury patients. Chin J Traumatol 2020; 23: 290-294.

26. Stewart ML, Biddle M, Thomas T. Evaluation of current feeding practices in the critically ill: a retrospective chart review. Intensive Crit Care Nurs 2017; 38: 24-30.

27. Chapple LS, Deane AM, Heyland DK. Energy and protein deficits throughout hospitalization in patients admitted with a traumatic brain injury. Clin Nutr 2016; 35: 13151322.

28. Nicolo M, Heyland DK, Chittams J, Sammarco T, Compher C. Clinical outcomes related to protein delivery in a critically ill population: a multicenter, multinational observation study. JPEN J Parenter Enteral Nutr 2016; 40: 45-51.

29. Chapple LA, Chapman M, Shalit N. Barriers to nutrition intervention for patients with a traumatic brain injury: views and attitudes of medical and nursing practitioners in the acute care setting. JPEN J Parenter Enter Nutr 2018; 42: 318-326.

30. Szczepanik AM, Walewska E, Ścisło L, Kózka M, Kłek S, Czupryna A, Kulig J. Ocena występowania niedożywienia u chorych z nowotworami złośliwymi przewodu pokarmowego. Probl Piel 2010; 18: 384-392.

31. Tejchman K, Suwała A. Albuminy - historia, fizjologia i rola w dzisiejszej terapii. Postęp Żyw Klin 2016; 4: 21-32.

\section{Address for correspondence:}

\section{Magdalena Staszkiewicz}

Department of Clinical Nursing

Institute of Nursing and Midwifery

Faculty of Health Sciences

Jagiellonian University

Medical College

Krakow, Poland

Phone: +48 783874294

E-mail: baranmagdalenaa@gmail.com 